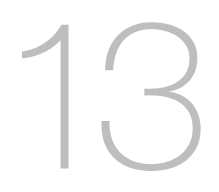

\title{
THE ROAD TO GENUINE PARTNERSHIPS WITH THE THIRD SECTOR: ARE WE THERE YET?
}

\author{
Peter Shergold \\ University of Western Sydney
}

\section{Liberation}

I am a 'liberated' public servant-I retired from the Australian Public Service (APS) six years ago. Nevertheless, I continue to serve on a range of government boards, councils and committees. Indeed I sometimes feel that I am more engaged with a wider range of public policy issues today than when I was a public servant. Living now in a world of 'care without responsibility', it's easy to think boldly about the future. It's easier to preach if you don't practise: the burden of administrative routine and political crises tend to overwhelm one's strategic impulse.

I hope I am not simply a blowhard. I strive to ensure that the enjoyment I get from being an agent provocateur on public administration is matched by active engagement in new approaches. I chair, for example, the NSW Social Investment Expert Advisory Group, overseeing one of the most interesting innovations in policy. Social Benefit Bonds involve the harnessing of private sector social finance for the creation of public good through a not-for-profit intermediary. It is a particular form of 'social impact investing'. The state's 
purpose is to attract private investors to fund early intervention by community providers. The original goal was to reduce the need to place at-risk children in out-of-home care, and to lower the rate and cost of prisoner recidivism, but the NSW government has now announced a significant widening of its ambition. If successful, the result will be significant budgetary savings and a more civil society. This represents a quite different way for a government to undertake its business.

Until taking a position as Chair of Opal Aged Care, I also headed the Commonwealth's Aged Care Reform Implementation Council and its successor, the Aged Care Sector Committee. In my recent address at the Leading Age Services Australia convention, I talked about the potential transformation of aged care delivery, focused in particular on the value of 'consumer-directed care' (CDC) approaches. This, too, represents an unorthodox approach to implementing publicly funded services. I envisage the possibility that as citizens become used to tailored, individualised, self-managed and 'self-directed' funding (not only in aged care but in the provision of disability services and mental illness support), they will become empowered. Instead of learning to be helpless recipients, they will be encouraged to take control of the government assistance they require. They will refuse to accept the constraints imposed upon their autonomy both by public service agency 'purchasers' and the third-party service 'providers' that presently deliver standardised services through block grant funding.

The main focus of this chapter, however, is on 'the road to genuine partnerships in the third sector'. This is another matter that arouses my passion. I served on the Western Australian Economic Audit Committee and, in particular, contributed to a volume that emphasised Putting the Public First (Economic Audit Committee 2009). For more than three years I then chaired the Partnership Forum that the report had recommended. This body brings together the key directors-general and not-for-profit CEOs in Western Australia. Together they negotiate more equitable financial arrangements for providers, simplify and streamline the administration of outsourced service delivery, and 'co-produce' program design. It was an energising experience because it was an initiative that actually walked the talk of collaboration. The strong support of the Premier, Colin Barnett, and the leadership of the Department of the Premier and Cabinet provided the necessary authorising environment.

More recently, I have worked with community organisations (particularly the Victorian Council of Social Services) and the Victorian government on new ways of improving collaboration in the development, as well as the delivery, of publicly funded human services (Shergold 2013). In response to my recommendations, which were based on extensive consultation with the state's not-for-profit sector, Minister Mary Wooldridge announced the establishment of a Community Sector Reform Council. Like WA's Partnership Forum, the Council's 
goal is to bring together senior representatives from across the government and non-government sectors to plan the implementation of reforms in the delivery of human services.

I also bring my interest in cross-sectoral collaboration to the NSW Public Service Commission Advisory Board, which I chair, and the Queensland Public Service Renewal Board, of which I am a member. Unfortunately, it was recently abolished by Annastacia Palaszczuk MP. In NSW, the board released a public report on collaborative partnership (NSW PSC Advisory Board 2014). Make no mistake: changes are afoot.

I still believe major reform in the public sector is an imperative, and new approaches are needed to improve performance. It is true that some of today's administrative creativity is partly driven by financial austerity or the buzz words going around - 'frugal innovation'. To be honest, however, I see the new approaches much more as 'disruptive innovation' - and my sympathies are very much on the side of the disruptors. Partnership approaches can reinvigorate the participatory nature of Australian democracy. They can build networked forms of governance. They can increase trust in the state and its institutions; create more flexible structures of public administration; and, in the process, help us to re-envision and revitalise the significant role of public servants.

That is what I hope for. Sometimes I think we might actually make it happen. Others, who are more cautious and less optimistic than I am, counter that public organisations tend to become trapped by their past. I do not think that organisational sclerosis is inevitable. Certainly I am doing my level best to try and make sure that public administration is not resistant or impervious to change. The desire of governments to deliver services more effectively, driven in part by budgetary pressures, will ensure that the status quo is challenged. Opportunities beckon.

\section{Embrace contractualism}

I want to tell a tale. This story may have begun before your time as a public administrator, or it may be a narrative in which you have been an active participant. Its beginning coincides with when I entered the public service a generation ago. It was a period when public services started to talk seriously about 'contestability' and 'outsourcing'. Often that discourse was associated, usually critically, with the so-called new public management. The focus was on 'managing for results'. One key element of that change process was the willingness to pay organisations outside the public service to deliver a government's programs and services. 
Some of you will remember what now seems a rather dated language: the organisational distinction between 'purchaser' and 'provider', and between 'steerer' and 'rower'. The terms, contractual or metaphorical, implied profound change in the nature of delivering government. Public servants would be required to benchmark their cost-effectiveness and evaluate their performance, and if there was 'value for money' in it, they would fund third parties to implement government policy under service agreements.

Part of the reform process was marked by the privatisation and corporatisation of government enterprise activities that had traditionally operated in the public domain. In the construction of public infrastructure it often took the form of public-private partnerships. In the area of human services it was epitomised by the contracting out of the delivery of support programs.

Perhaps delivery of services through third parties seemed newer than it was. Gary Sturgess (see his chapter in this volume) is quite right: the popular notion that Australian governments had traditionally delivered public services only through public servants is ahistorical. If you are a student of colonial Australia, you will be aware that so much of what we now consider the role of the public service was initially provided by the business or community sector - whether it was Australia's first charity, the Sydney Benevolent Society, which supplied health, nursing and a range of essential social services; or the Australian Mutual Provident Society, which wrote its first policies in 1849, one of a number of mutual and friendly societies which provided funeral benefits and life insurance; or the range of agricultural and retail cooperatives, which redistributed their profits back to members. Contracting out government was commonplace. It was, to revert to my earlier work as an economic historian, the primary means of transporting convicts to NSW. Nevertheless, to many public servants in the early 1990s, the contracting of not-for-profits to deliver government programs appeared as the shock of the new.

It was, I remember, a matter of fierce political debate. I found the process quite exciting. What most interested me at the time was the development and delivery of family and community support, disability care, employment and training, Aboriginal affairs, education, health services, and aged care. In those areas implementation was predominantly, although by no means exclusively, outsourced to community-based organisations.

As Secretary of the Department of Employment, I had particular responsibility for the early days of the Job Network (now Job Services Australia). I supervised the second tender process, at the conclusion of which the delivery of employment services was divided more or less evenly between the private and not-for-profit sectors. It was apparent that public sector organisations such as Employment National found it hard to compete. For 50 years, labour market brokerage had 
been largely a government monopoly, provided by a network of Commonwealth Employment Service offices. Now, in the mid-1990s, the delivery of services was moved out of the APS.

Similar developments occurred in many other areas of public policy. Today, at both the state and Commonwealth levels, a wide range of human services is delivered not by public servants but by contracted providers, predominantly in the community sector. Critics, usually in academia, sometimes characterise this development as the emergence of the 'contract state' or the 'hollow crown'. I see it differently. I was a naïve enthusiast in the 1990s, and I remain a wiser (more chastened) supporter today. My major frustration is that the potential of commissioning service delivery has too often been undermined by administrative red tape.

The scale of outsourcing is enormous. The 2010 Productivity Commission research report on the contribution of the not-for-profit sector found that each year about $\$ 26$ billion of government services was delivered directly through the sector. This is a profound transformation. The amazing thing is that most Australians do not really understand it, nor are they even fully aware of it. It has happened largely beneath the radar of public opinion. Not-for-profit organisations that traditionally saw themselves as charities, and often as advocacy organisations, are now regarded by public services as 'government service providers'. I emphasise that this is not how most of them see themselves.

I witnessed this change take place at first hand. When I entered the public service, my task was to set up the Office of Multicultural Affairs (OMA). Together with the Department of Immigration, OMA made many grants to ethnic groups and migrant centres that provided settlement services. Most of those grants were intended to subsidise what community organisations were already doing of their own accord. In other words, government assessed that their activities were beneficial and in the public interest, and so provided small grants of public money to assist them. Accountability was based on acquittal. This is a very different approach to the typical relationship today. Most of the direct government funding now takes the form of contracts: they are intended not to supplement community-developed public services but to deliver the government's programs.

The implications of this change are often inadequately comprehended. Neither side of the contractual equation-public service purchasers on the one hand and not-for-profit providers on the other-has clearly appreciated the substantive difference between a grant subsidy and a payment-for-service agreement. Too many of the contracts that are being written remain ambiguous in their nature. This is unfortunate. Trust depends on both sides entering into a relationship with eyes wide open. 


\section{Experimental transformation through cooperative partnerships}

I continue to believe that outsourcing the delivery of government human services to 'third sector' community organisations is a good thing. Scores of evaluations leave me in little doubt that in most cases the provision of programs through the not-for-profit sector has resulted in better quality services being delivered to clients at a lower cost. This is not unequivocally a good outcome. Many community organisations that tender for contracts may end up effectively cross-subsidising government for the delivery of services. In other words, community organisations - which raise funds from donors for charitable purposes, employ workers at lower wage rates than public servants, and make extensive use of volunteers - may find themselves delivering services at below their real cost. Their mission (to help those in need) persuades them to do it. PricewaterhouseCoopers estimated that in WA, community organisations were generally being paid about 30 per cent less than the true cost of service delivery. I suspect that situation would not be different in other jurisdictions. It is to the great credit of Premier Colin Barnett that he addressed that underpayment in his state's 2011 budget. He saw it as the first essential down payment on partnership.

So whilst I am still supportive of contracting the community sector, I believe that the relationship needs to be made over. In my view the potential revolution in public administration has only been half-fulfilled. The aim of outsourcing should be to create a wider diversity of providers, greater choice for users, and more experimentation in delivery. Instead, there is a bureaucratic impulse to standardise programs, to control delivery processes, to micromanage the service agreements and to avoid risk. It is time to pause, reassess and rethink where we have arrived, and consider where we should go from here.

We have the capacity to create a 'public economy' that is delivered by a crosssectoral collaboration between public, private and not-for-profit organisations. Governments need to set, tender and pay deliverers on the basis of agreed outcomes. The ambition should be to provide citizens in need with flexible options. The arrangements should encourage social entrepreneurship. We need to stop perceiving contractual relationships, built over a quarter of a century, as merely transactional. Let us instead ask the question: How can we do things differently so that the process can become transformational? The answer, I believe, is to build collaborative relationships which allow public servants and community workers to design in a cooperative fashion the best ways to maximise value for the expenditure of public funds. 
Let us stop thinking about how to build 'mind labs' and 'design centres' at the periphery of public administration. Let us instead seek to change the core. Let us harness the power of partnership to develop and deliver government services on behalf of government in ways that empower the citizens that access them.

\section{Promoting a collaborative environment}

There are four distinct aspects to the creation of a public economy.

First, we need to do more to appreciate and embrace the experience of community organisations. Many of them have been in this game for a long time, and their workers have considerable frontline experience. Imagine how it must appear for many of these not-for-profits: a government decides on policy and announces it; a public service department, either through legislative or administrative means, translates that policy into particular services and programs; the contracts and guidelines are written to protect the government from risk; and only at that final stage is the delivery of the policy tendered out. Consider how it would feel to be at this low-value end of the development chain - especially if you believe that if your organisation had been consulted at an earlier stage, the programs and services could have been better formulated. 'Co-production' and 'co-design' are the keys to maximising public value and beneficial social impact.

Second, we need to encourage the latent entrepreneurship of community organisations. Of course things are tough-governments face an environment of shrinking revenues and soaring demand. But which businesses in Australia typically live in an austerity environment, often not knowing from year to year how they are going to survive? Answer: those in the community sector. Their constant struggle to pursue their mission whilst ensuring financial sustainability drives a willingness to embrace considered risk-taking. Unfortunately, when governments contract those enterprises, they often constrain organisational creativity by imposing an unnecessary burden of regulatory controls. Outsourcing should present an opportunity for diversity: it should be a means to challenge a variety of organisations - whether private or community-based - to come up with new and exciting ways of delivering the public interest.

Third, we should learn from 'the wisdom of the crowd'. Here I am talking as much about frontline public servants as community organisation employees. If you monitor the work of public servants at the most junior levels, you will often observe a remarkable degree of innovation. Unfortunately, it is to a significant extent diverted into developing the day-to-day 'workarounds' that enable staff to subvert the inflexible administrative guidelines under which 
they operate. We should learn from people at the grassroots level, and provide them with greater autonomy in the ways in which they deliver the outcomes sought by government. Bureaucratic hierarchy may provide an effective basis for quality control, but it can also diminish the capacity of policy to be informed by experience. We need to get more serious about devolving responsibility down the line. We need to value experience more highly.

Finally, we should seek to attract social finance from the private sector. Social Benefit Bonds (see Walker's chapter in this volume) are an exciting new financial instrument, but they represent only one small part of 'impact investing'. Governments can provide capital loans on a low-interest basis to 'social enterprises', allowing them to start up or to scale their growth. Social enterprises are not-for-profit organisations that raise revenue through engaging in trade, including through the delivery of government services, and then invest any surplus in their social mission. Governments would do well to help those enterprises to grow. Governments can make social investment more financially attractive. They can support financial intermediaries to provide capital (equity or debt) to social enterprises.

\section{Facilitating genuine relationships - there is hope}

Governments can act to promote a more collaborative environment. They can encourage public sector leaders to themselves become 'intrapreneurs', pushing change from the inside. We know public servants are good at this: in the last 25 years of public administration, most of the key reforms have been driven from within. Many public servants have the capacity and the will to do this; they just need the government authority and encouragement to act.

There exists an opportunity to push public sector innovation from the central point of the Venn axis at which public/private/not-for-profit engagement cross over. In the area of human services, in particular, contracted organisations should be afforded a genuine opportunity to contribute to policy. They should be enabled to participate actively in the design of more integrated and holistic wraparound services. Of course they should be paid and held publicly accountable on the basis of outcomes - but outcomes delivered in their own way, without unnecessary interference. That will make it possible for governments to move away from the delivery of templated programs. To my mind, it does not make sense to move delivery from the public service to a range of businesses and not-for-profit organisations, and then dictate that the service they provide must be implemented and managed in one particular way. It is possible to release the transformational potential of outsourcing by accepting that different organisations will have different ways of delivering outcomes and, by doing 
so, they will enable citizens to have a real choice in the services available. This, above all, should be the motive driving governments to commission the execution of their political goals.

That objective will be enhanced by an extension of local solutions - and by that I do not simply mean the regional demarcations that public servants construct for administrative convenience. I am talking about 'place-based approaches' that can be implemented at the level of urban neighbourhoods, remote townships, or Aboriginal settlements. I am also talking about devolving decision-making to schools, hospitals and social housing estates. These 'communities' should be afforded more opportunity to make their own choices and be given greater responsibility to use the government funds at their disposal.

The value of outsourcing will be enhanced by putting citizens in control of the services they need to live a full life. That means giving them the opportunity to manage their own budgets, to select their own services and to choose their own providers. This is not intended to diminish the responsibility or the status of public administration, but it does require the role and situational authority of public servants to be redefined.

The public service leaders of the future will be facilitators. They will be empathetic listeners, skilled negotiators, team-based designers and effective coordinators. In other words, public servants will play a crucial role as partners in the delivery of 'network governance'. They will be the stewards of public value and accountability, bringing together diverse actors that collectively give effect to the will of the state. This, then, will place them at the centre of a public economy, in which 'private-for-purpose' businesses, 'surplus-for-mission' social enterprises and the 'public-qua-public' agencies collaborate in the delivery of public value in the most effective manner.

The good news is that all of this can be done. The future is already with us - it is just not evenly distributed yet. When we talk about the potential of consumerdirected care, local-based solutions, cross-sectoral collaboration or social impact investing, we know that examples already exist. The innovative pilots, demonstrations and trials that are already underway need to be evaluated and, if successful, to take their place at the centre of mainstream public administration. That is the horizon at the end of the road to genuine partnership. We are not there yet but we are on our way. 


\section{References}

Economic Audit Committee. 2009. 'Putting the Public First: Partnering with the Community and Business to Deliver Outcomes.' Perth: Government of Western Australia.

New South Wales Public Service Commission Advisory Board (NSW PSC Advisory Board). 2014. Doing Things Differently: Raising Productivity, Improving Service and Enhancing Collaboration across the NSW Public Sector. Sydney: New South Wales Public Service Commission. Online: http://www. psc.nsw.gov.au (accessed 30 March 2015).

Productivity Commission. 2010. 'Contribution of the Not-for-Profit Sector.' Research Report, January. Online: www.pc.gov.au/inquiries/completed/notfor-profit/report/not-for-profit-report.pdf (accessed 11 June 2015).

Shergold, Peter. 2013. Service Sector Reform: A Roadmap for Community and Human Services Reform. Melbourne: Department of Human Services. Online: vcoss.org.au/documents/2013/11/FINAL-Report-Service-Sector-Reform.pdf (accessed 11 June 2015).

Shergold, Peter. 2013. 'Risk-ready: It's time for innovation.' Insight 7: 2830. Online: www.vcoss.org.au/documents/VCOSS\%20docs/insight/07/ Insight_07_Risk-ready.pdf (accessed 4 February 2014).

Shergold, Peter. 2014. 'Community services without the red tape.' Australian, 16 January. 
This text is taken from Managing Under Austerity, Delivering Under Pressure, edited by John Wanna, Hsu-Ann Lee and Sophie Yates, published 2015 by ANU Press, The Australian National University, Canberra, Australia. 